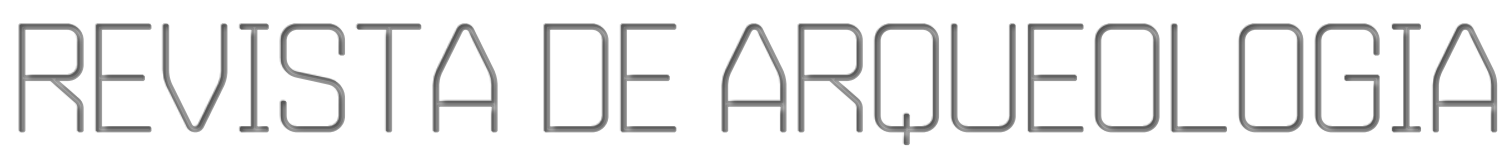

Volume 33 No. 2 Maio-Agosto 2020

\title{
DEIXA MEU CABELO EM PAZ E OUTROS CONTOS SOBRE ARQUEOLOGIA DO RACISMO À BRASILEIRA
}

\section{Rafael de Abreu e Souza*}

\section{RESUMO}

Este texto explora possibilidades a uma arqueologia do racismo à brasileira com base em uma auto-arqueologia do passado contemporâneo para o Brasil. Ressalta questões relacionadas à ausência de reflexões sobre o problema na prática arqueológica. Navega pela materialidade de símbolos de opressão que são sutis e discretos, como o próprio racismo à brasileira, que o sustentam, o reproduzem e o materializam, trazendo dor, humilhação, crueldade e destruição. Sugere que a raiva pela qual passamos na profissão e os projetos arqueológicos em torno de temas que abordem a presença e o legado dos africanos no Brasil dão base material a afirmações que podem nos ajudar a lutar por representações a partir de nossos lugares de fala.

Palavras-chave: racismo à brasileira; objetos racistas e racializados; autoarqueologia.

\footnotetext{
* Doutor em Arqueologia, Museu de Arqueologia e Etnologia, Universidade de São Paulo.

E-mail: rafaelabreusouza@gmail.com. ORCID: https://orcid.org/0000-0002-1963-5394.
} 


\section{LET MY HAIR ALONE AND FURTHER STORIES ABOUT THE ARCHAEOLOGY OF BRAZILIAN RACISM}

\section{ABSTRACT}

The paper raises possible avenues for an archaeology of Brazilian racism through an auto-archaeology of the contemporary past. It highlights the absence of critical thinking about the problem within the archaeological practice. It navigates through the materiality of symbols of oppression, which are subtle and discrete as Brazilian racism itself, sustaining, reproducing and materializing an ideology that brings pain, humiliation, cruelty, and destruction. The paper suggests that archaeological projects focused on the presence and legacy of Africans in Brazil can provide the material base for self-affirmative initiatives to help us fight for our places of speech and representativeness.

Keywords: Brazilian racism; racist and racialized objects; auto-archaeology.

\section{DEJA A MI PELO EN PAZ Y OTRAS HISTORIAS SOBRE LA ARQUEOLOGÍA DEL RACISMO BRASILEÑO}

RESUMEN

Este texto tiene como objetivo abordar las posibilidades de una arqueología del racismo brasileño desde una auto-arqueología del pasado contemporáneo. Destaca cuestiones relacionadas a la ausencia de reflexiones sobre el problema en la práctica arqueológica. Navega por la materialidad de los símbolos de opresión que son sutiles y discretos, como el propio racismo brasileño, que lo sostiene, reproduce y materializa, trayendo dolor, humillación, crueldad y destrucción. Sugiere que el enfado que sentimos en la profesión y los proyectos arqueológicos sobre la presencia y el legado de los africanos en Brasil proveen una base material para autoafirmaciones que nos ayudan a luchar por lugares de habla y representatividad.

Palabras clave: racismo brasileño; objetos racistas; auto-arqueología. 
Até lá na escola já não posso estudar Com meu cabelo grande o diretor não deixa entrar Deixa meu cabelo em paz, seu diretor Deixa meu cabelo em paz Oswaldo Nunes, Deixa meu cabelo em paz, 1971

A professora olhou meus joelhos ressecados pelas brincadeiras com a turma e disse na frente de todos que eu era sujo. Eu sabia o que era isso: racismo. Naquela tarde, passei horas no banho chorando, questionando e culpando minha mãe por não ter nascido branco. Eu tinha seis anos. Na turma só havia outra criança que apresentava traços da negritude e que não se identificava como branco. Ele morava no morro da Mangueira e anos atrás faleceu de dengue. O filho do bicheiro nos chamava de "macaco". A partir daí eu acumularia dezenas de experiências, como explicou Franz Fanon (2008, p. 95), que são parte da concretização das formas como nossa sociedade, para manter sua consistência, nos inferioriza, desumaniza e objetifica por meio da reprodução de práticas racistas.

Quantas pessoas negras havia nas disciplinas que fiz? Nenhuma? Duas? Quantos docentes? Nenhum. Em 2015, uma pesquisa sobre o perfil dos professores e professoras da Universidade de São Paulo revelou que 1.83\% e 1.53\% se autodeclaravam negros e pardos, respectivamente, contra um total de $94.6 \%$ de autodeclarantes brancos (MARTINS, 2017). Tais situações de "confinamento racial” (CARVALHO, 2005-2006, p. 92), herdadas de gerações acadêmicas passadas, e sobre as quais não refletimos muito, também ocorrem na arqueologia.

Nas equipes de campo com as quais trabalhei, quase todos se identificavam brancos, poucos recorriam às centenas de nomes que o Brasil possui para cores de pele, e quase ninguém era negro. Certa vez, depois de horas sob o sol durante uma prospecção, me chamaram de "tição": termo comum usado para designar pedaços de lenha queimada e o Diabo. Engoli a seco, também durante um trabalho de campo, ao comentário sobre a rebelião em um presídio, quando cabeças de detentos decepadas foram mostradas na televisão: "mas olha a cor? Só podia ser preto". Esses são exemplos mais do que clássicos do uso de metáforas ("tição", "macaco") e ironias ("só podia ser....") para dar forma ao significado racial interdito típico que manifesta o racismo à brasileira em nosso dia a dia (SALES JÚNIOR, 2006, p. 241).

E eu não retrucava. Nunca. As piadas racistas nas escavações vinham como comentários baseados na cor, no cabelo ou no nariz e, como toda piada, tinha o intuito de provocar risos, marginalizando e dissimulando conflitos (FONSECA, 2012). Rir me incluía ou me excluía imediatamente. Eles não percebiam? Não. Eu havia embranquecido, eu havia ascendido socialmente e superado expectativas esperadas para mim: quanto mais eu me graduava, viajava, aprendia idiomas, mais branco eu me tornava, mais aceitação social ocorria e mais eram os nomes do colorismo - termo cunhado nos anos de 1980 para explicar o preconceito ou tratamento preferencial baseado na cor de pele - que se proliferavam (NORWOOD, 2015, p. 586; NASCIMENTO, 2018, p. 59).

"Moreninho" é o que eu mais detesto, um eufemismo racial que se esconde em nossa forma de utilizar os diminutivos para suavizar conflitos. Moreno foi como cresci, como minha avó negra e filha de santo me chamava. Mas sempre mudei de cor dependendo da região, entre Rio Grande e Salvador, fruto da variação sociocultural e político-econômica própria das classificações de cor de pele aqui: "negro", "moreno", "cinza", "verde", "amarelo" são alguns dos termos como, dependendo da situação, descrevo a mim mesmo e confundo os estrangeiros de língua inglesa em suas categorias binárias. No entanto, como muitos, sou mais claro para a academia e mais escuro para a polícia e para os seguranças, que me seguiam nos supermercados e me abordavam no campus, em uma 
clara relação entre paisagem e poder, entre os usos e sentidos do lugar e a materialização da desigualdade.

Para este artigo, parto de uma abordagem auto-arqueológica, a fim de estabelecer possibilidades para pensar criticamente o contemporâneo, observando, como arqueólogo, o universo que me cerca (HARRISON; SCHOFIELD, 2009). Essa arqueologia vincula experiências pessoais, que são coletivas, e crítica científica, no intuito de ampliar temáticas tomando como base as coisas com as quais compartilhamos nossas vidas. No esforço de uma arqueologia familiar, próxima e relevante, que escava nossas próprias memórias, essa arqueologia é uma ação política no presente (MCGUIRE, 1999).

Meu objetivo é abordar o racismo no Brasil pela arqueologia. Sigo a toada de uma disciplina cada vez mais politizada e marcada pelas experiências de vida e preocupações pessoais dos próprios arqueólogos (MESKELL, 2002, p. 280). Olho a cultura hegemônica e suas estratégias de controle pela discriminação e opressão aos traços materiais e a corporalidade da negritude a partir de um ponto de vista "de dentro", enveredando pelas ambiguidades da cultura material na crítica à ordem dominante (MATHEWS et al., 2002, p.122). Afinal, que formas o racismo adquire no mundo material e de que forma o mundo material materializa o racismo? (MULLINS, 2006, p. 64).

Começo o texto considerando as possibilidades de pensar a dimensão material estrutural do chamado racismo à brasileira. Sigo abordando o tema dos objetos racistas e racializados no âmbito da materialidade da opressão, dando foco aos artefatos, que, discretos e ubíquos, têm potência na manutenção e reprodução da discriminação e do preconceito - pentes, bonecas, bonés, latas. Relaciono esse contexto aos materiais, que, sobrepostos às categorias racializantes de cor, nos tornam alvo pela concretização de estereótipos e construção de marcadores de marginalização e exclusão por associação. Finalizo ressaltando como a materialização desse preconceito relaciona-se ao medo do diferente e à banalização da violência que vem manifestando o que há de pior no biopoder: a eliminação física da nossa existência.

\section{A ESTRUTURALIDADE DO RACISMO A BRASILEIRA}

Situações como as descritas acima repetem-se e podem ser encontradas em qualquer conversa por aí, na literatura acadêmica, na mídia e nas redes sociais. Descobrir que elas não são apenas individuais, que não sou eu, é libertador: é o racismo que é estrutural e não conjuntural, como esclarece Silvio Almeida (2018). Entendê-lo apenas como pontual discriminação ignora seu infeliz papel nos padrões de normalidade das relações sociais, nas formas de racionalidade e compreensão dessas relações e no estabelecimento de relações de poder cristalizando vulnerabilidades e privilégios. O racismo é desafortunadamente uma estrutura social que rege o funcionamento corrente da vida cotidiana, tornando o constrangimento e a discriminação direta partes inerentes dessa dinâmica (ALMEIDA, 2018).

Tais constrangimentos evidenciam as dimensões materiais de dispositivos opressivos, como definiu Michel Foucault (1988), enquanto redes tecidas entre discursos, instituições, materialidades e leis que respondem a funções estratégicas: seja pelo corpo ou por materialidades relacionadas a estéticas que inferiorizam, demonizam, excluem expressões culturais e violentam identidades, sofreremos opressões relacionadas a como somos entendidos física, visual e materialmente. E, claro, não sofrerei essa opressão pelos meus traços brancos, mas pelos traços de minha negritude.

Assim, foi chocante ouvir que não havia racismo no Brasil, em um círculo de arqueólogos que se identificavam brancos, que fizeram intercâmbio e aulas de línguas. Que não se deve "trabalhar por dinheiro" é outra expressão comum na arqueologia, em especial na crítica à arqueologia de contrato, mas não só. A expressão soa fruto de um 
passado burguês no qual a família arcava com todos os gastos da filha ou filho que desejou ser arqueólogo: essa não é a realidade da maioria, em especial da geração formada após 2004 com o início dos cursos de graduação em arqueologia, e a expressão é não só simplista como ofensiva. Não acho que meus pais venderam sua alma ao capital para encher o bolso de dinheiro.

O trabalho como arqueólogo e a regulamentação da profissão devem levar em conta como o sistema trabalhista, as tributações e a reprodução das condições de desigualdade de raça-classe-gênero (ALMEIDA, 2018) estão presentes na área, expressas nas diferenças salariais e de ofertas de emprego, na própria divisão entre campo e laboratório e na diferença entre os valores das bolsas de iniciação científica e o salário dos professores universitários. Além disso, a universidade não só não vai empregar todos os arqueólogos formados no país como não deveria ser entendida como a única via digna de trabalho e produção de conhecimento, como parece referir-se constantemente. Se quiser ser vista como emancipadora e libertária, ela terá que reconhecer que falamos e partimos de lugares distintos.

O debate sobre o tema do racismo na arqueologia brasileira inexiste. Tampouco discussões sobre como o sistema de privilégios e oportunidades operantes na própria arqueologia modelou a disciplina. Pouco ou nada foi abordado em torno da materialidade do racismo, do uso de lógicas racistas nas interpretações arqueológicas ou das "cumplicidades racistas da arqueologia" (CARLE et al., 2018). Tal ausência é pano de fundo para o esquecimento de categorias estruturantes de opressão e exploração (GONZALEZ, 1988), como o machismo, a misoginia, a homofobia, a transfobia ou a gordofobia. A falta de representatividade na arqueologia brasileira também mostra como ela está profundamente ligada à realidade que a cerca e à exclusão de populações negras, indígenas e de seus descendentes das esferas produtoras de capital científico.

Representatividades são poderosas em ampliar olhares, a exemplo de como a arqueologia poderia denunciar a branquitude como lugar de privilégios materiais. A presença de borrões azuis na casa grande e no sobrado, sendo escolhas de consumo e gostos culturais, e sua ausência e frequência diferencial na senzala, interpretadas a partir de paradigmas contextuais arqueológicos, como recorrência e associação, não poderiam ser entendidas como sinais dos privilégios ao acesso a determinados bens durante a escravidão? Afinal, estruturas ideológicas racistas estão presentes nos modos como as pessoas se relacionam umas com as outras e, por isso, podem deixar vestígios materiais (ORSER JR., 1999, p. 663). A história da arqueologia latino-americana e o estudo de suas raízes ideológicas têm mostrado como raça e racismo foram utilizados para sustentar interpretações arqueológicas (CURTONI; POLITIS, 2006, p.93; FERREIRA, 2002).

Esta sustentação relaciona-se ao racismo à brasileira sendo aquele que, diferente de contextos com claros aparatos legais segregacionistas, como ocorreu nos EUA e na África do Sul, é zeloso, engenhoso e sutil, aparece de maneira dissimulada e mascarada, e por isso eficiente em sua função, difícil de erradicar e de identificar mesmo para quem sofre (CAMINO et al. , 2001, p. 22). Se o racismo e o preconceito gritam no silêncio, sua materialização se dá por meios onipresentes e discretos, manifestando-se de modo rasteiro, mas feroz, esgueirando-se sorrateira pela naturalidade e obviedade das relações sociais, frequentemente atuando pela humilhação soturna e exclusão perniciosa.

No Brasil, momento fundamental à consolidação do racismo à brasileira ocorreu em meados do século XIX, quando se tornou doutrina científica no escopo da cena política que se direcionava ao fim da escravidão. O racismo científico sustentou o modo como as elites intelectuais reagiram às diferenças regionais crescentes entre Norte e Sul do país, utilizando-o em escolas de medicina e criminalística como forma de explicar desigualdades e outros problemas de cunho social (SCHWARCZ, 1993; GUIMARÃES, 
2004). O racismo à brasileira encontrou voz junto do chamado "mito da democracia racial”, no qual três raças, a africana, a europeia e a indígena, após um intenso processo de mestiçagem nos trópicos, viveriam em perfeita harmonia, todo mundo junto e misturado. Apesar da importância dos elementos europeus, africanos e indígenas no Brasil, seu uso como recurso na construção da identidade nacional concretizou-se como ideologia dominante, como mostrou Roberto DaMatta (1990, p. 63).

\section{A MATERIALIDADE DO RACISMO À BRASILEIRA}

As arqueologias do passado contemporâneo são um campo em expansão (BUCHLI; LUCAS, 2001; SCHOFIELD, 2010; GONZÁLEZ-RUIBAL, 2016). Ascenderam acompanhadas de novos temas, paradigmas e tentativas de tornar a arqueologia menos dependente dos aportes teórico-metodológicos das outras ciências sociais (GONZÁLEZRUIBAL, 2012). Elas implicam uma maior contextualização dos assuntos abordados, justamente devido ao jogo do familiar/não familiar e do incentivo a que os arqueólogos pensem sobre as idiossincrasias que compartilham com suas próprias realidades (GRAVES-BROWN, 2011).

Existem diversos temas pelos quais a arqueologia do passado contemporâneo no Brasil pode enveredar e que ainda estão por acontecer ou crescer, como arqueologias que abordem a construção material da identidade nacional (por que não uma arqueologia do futebol ou do carnaval?), a repressão, a resistência e a subversão frente aos nossos constantes regimes ditatoriais (BARETTA, 2017), e uma arqueologia da paisagem dos conflitos fundiários frente à duradoura exploração e expropriação do campo e do campesinato (CORSO, 2010). Também o racismo como tema que nos é caro enquanto ideologia arraigada em mentes e estruturas, que atua como se não estivesse, que faz com que a maioria dos brasileiros não se reconheça racista, mas admita estar cercado por pessoas racistas (SCHWARCZ, 1996, p. 155), pode ser pensando arqueologicamente.

Nossa arqueologia do passado contemporâneo é diferente da dos países do Norte geopolítico pelo próprio entendimento do que é "contemporâneo", pela proximidade com a arqueologia histórica, e pela particularidade de problemáticas caras a nossa realidade, como a opressão, a repressão e a resistência a elas. Não existe uma arqueologia do racismo à brasileira que não quebre os limites temporais aos quais a arqueologia está submetida, devendo, ao fugir de analogia diretas, explorar as nuances do longo processo material que estruturou formas de opressão baseadas fundamentalmente em corpos, coisas e lugares de pessoas que ainda compartilham experiências semelhantes: nós (BABSON, 1990, p. 20).

Uma arqueologia do passado contemporâneo do racismo à brasileira incluiria necessariamente a escravidão, desse modo sobrepondo-se à arqueologia histórica na busca das genealogias desse lado obscuro da modernidade (GONZÁLEZ-RUIBAL; ALMUDENA, 2010); englobaria a imposição de classificações raciais no final do século XV como pedra angular da colonialidade e da modernidade que assolaram a América (QUIJANO, 2014, p. 286); ou, ao menos, teria que considerar o momento no qual o racismo científico passou a ser utilizado como perspectiva para entender e lidar com uma nação extremamente mestiça (SCHWARCZ, 1996).

É claro que o racismo tem dimensões materiais e não é diferente do racismo à brasileira. Como fenômeno sociopolítico expresso na dominação de um grupo por outro e na crença de sua superioridade a partir de diferenças fenotípicas (MUNANGA, 1990, p. 110), sua materialidade é sua própria causa e consequência, e está na base de sua reprodutibilidade. A contribuição da arqueologia ao racismo à brasileira está justamente em sua capacidade, por excelência e teimosia, de relembrar que as coisas existem e que têm qualidades reais que afetam nossa percepção e nossa relação com elas (OLSEN, 2003, 
p. 89). A arqueologia é hábil em ressaltar cronológica e espacialmente as formas como certas corporalidades são produzidas, reproduzidas e transformadas na socialização dos indivíduos, e em perceber como a materialidade de práticas, ideias e experiências racistas submete nosso corpo (JOYCE, 2005, p. 140).

Além disso, a arqueologia da escravidão e da diáspora africana é uma das frentes arqueológicas mais reconhecidas por historiadores e antropólogos sociais, a exemplo dos trabalhos de Camila Agostini, Marcos Souza e Luís Symanski (AGOSTINI, 2013; SANTOS et al., 2018). Estou longe de ser um especialista no campo, tarefa bem empenhada por diversos pesquisadores (FUNARI, 1991; FERREIRA, 2009; SOUZA, 2013; SYMANSKI, 2014; AGOSTINI, 2019). Neste texto, todavia, dialogo com ela no sentido da crítica ao racismo como ideologia cuja natureza sistêmica e dimensão material estão no cerne das assimetrias de poder e desigualdades que nos cercam, bem como em sua própria reprodutibilidade como elemento-chave da biopolítica do Estado (MBEMBÉ, 2018). Esse processo tem raízes na escravidão e desenvolvimento a partir dela. Além do mais, considero-me descendente direto dessa diáspora.

O racismo materializa-se de diversas formas e em distintas escalas, como, por exemplo, nos objetos racistas e racializados (SCHAMBERGER, 2010). Podem os objetos ser racistas? Sim, se eles carregam, acionam e atuam nas possibilidades opressivas de materialidades cruéis, humilhantes e excludentes. Os mais óbvios são, claro, os objetos que compõe a tecnologia punitiva da escravidão, como grilhões ou máscaras. Para além dos objetos, a paisagem também pode ser racista na medida em que o espaço construído pelas relações sociais entre senzala e fazenda é racializado, na oposição entre periferia e centro da cidade ou, ainda, na calçada que é cruzada quando caminhamos na direção de alguém que obviamente sente medo de nós. Contudo há outros materiais muito mais perniciosos, cujo racismo incólume não está só na morfologia, mas no conteúdo da relação entre uso e forma que orienta sua performance, e nas associações com outros objetos e corpos no espaço.

Diante disso, a noção de raça prescinde de sua fundamentação no mundo físico, materializada em uma cultura a qual permite que o opressor transforme tudo a seu redor em objeto de dominação, incluindo coisas, paisagens e corpos (LEONARDO, 2009, p. 172). Assim, coisas, paisagens e corpos tornam-se objetos que legitimam controles e normalizam relações de poder, nomeando, classificando, disciplinado e patrulhando fronteiras sociais (BAL, 2017, p. 9). Ao pensarmos na cultura material do cuidado-de-si, por exemplo, a imposição do uso de pentes que são tudo menos ergonômicos para cabelos crespos, fica explícita a exclusão de todo um grupo social pelas possibilidades assimétricas do ter, em um mundo no qual justamente para "ser" é preciso "ter" (DELEUZE; GUATARRI, 1995). É assim que o pente se torna um objeto racista, parte das políticas do fora do lugar, do não se encaixar e do não fazer parte, sublimadas pelo racismo através da privação de possibilidades de construções de identidades pelo consumo.

Os objetos que materializam esse racismo atuam no silêncio e são habilidosos, reproduzindo-o por meio da perpetuação de suas narrativas, estereótipos e práticas. Muito da cultura material foi criado, ressignificado e apropriado para assistir a esse processo de racialização, sustentando práticas de dominação (ORSER JR., 2007). Por isso, e por serem envolvidas em como sujeitos se apresentam socialmente, as coisas são um ponto de entrada privilegiado para entender as dinâmicas racistas e raciais que imperam no contemporâneo brasileiro (MIZRAHI, 2015, p. 31).

Por enquanto, os EUA, a Austrália e a África do Sul têm liderado os debates sobre a arqueologia do racismo (ECHO-HAWK; ZIMMERMAN, 2006; SYMANSKI, 2014, p. 72). Todavia suas abordagens e temas fazem sentido a realidades localizadas, mesmo com 
a forte tendência universalista da produção científica do Norte. Apesar de semelhanças quanto às problemáticas em torno de paisagens racializadas, estruturas do racismo e mecânicas da opressão, a produção anglo-saxã parte de pressupostos como o do multiculturalismo, das identidades hifenizadas e de categorias cuja compreensão e uso no Brasil são outros, em especial na diferença entre o racismo de sangue estadunidense e o racismo de cor de pele brasileiro (MUNANGA, 2005-2006, p. 53).

Neste âmbito, o racismo à brasileira é um espaço privilegiado para a reflexão em torno da dimensão material de processos de desigualdade, dado ao fato de, no Brasil, o preconceito ser uma marca física e implicar em reconhecimento quase imediato, oposto ao preconceito de origem, corrente na América Anglo-Saxã, onde o racismo se manifesta a despeito da aparência (SCHWARCZ, 2012, p.100).

\section{OBJETOS RACISTAS E RACIALIZADOS}

Passaram-se anos até que minha mãe encontrasse bonecas e bonecos negros onde morávamos, desde que nasci, no final do regime militar. Apenas em meado dos anos 1990 finalmente chegaram às lojas Luan e Luana, modelos produzidos e oficialmente assim nomeados pelas Indústrias Reunidas Balila, que os fabricou entre 1991 e 1994, mas que, pensávamos à época, haviam sido batizados por nós mesmos. A Balila, fundada nos anos de 1950, especializou-se na produção de brinquedos de plástico e, junto de outras fábricas, como Bandeirantes, Trol, Estrela, Metalma, Mimo e Beija-Flor, introduziu os polímeros sintéticos no cotidiano do universo infantil a partir do parque industrial paulista (GARCIA, 2017; ELY, 2017).

Não é de hoje que brinquedos infantis têm papel fundamental na naturalização de modelos modernos de organização social e ideologias, legitimando tipos e ideias como universais e corretos (PEARSON; MULLINS, 1999; ZARANKIN; SALERNO, 2015). Nesse contexto, bonecas como Luan e Luana circularam em realidades marcadas por desigualdades de classe, raça e gênero e só têm sentido se pensadas no âmbito da materialização de estruturas de poder e na dimensão material da desigualdade cedo na vida das pessoas (CHIN, 2001, p.130; MARTIN, 2014).

Os anos de 1980 assistiram, com o fim da ditadura cívico-militar brasileira e o estabelecimento da constituição cidadã, o investimento de algumas fábricas em brinquedos "etnicamente corretos", produzidos com distintas aparências que incluíam cabelos de diferentes texturas. Essa produção fez parte das críticas a bonecas e bonecos que feririam a dignidade de crianças negras, contribuindo para a negação do pertencimento e sua baixa autoestima (MARQUES, 1996; LEMES, 2015).

Tendo isso em vista, uma vez que a autoidentificação é fundamental para a crítica aos papéis sociais e processos de empoderamento, fica claro que a materialidade dos brinquedos tem extrema relação com a autoestima. Apesar de, segundo o IBGE, quase $54 \%$ da população brasileira afirmar suas origens africanas, em 2016, o projeto "Cadê nossa boneca?", da ONG Avante, diagnosticou que a produção de bonecas e bonecos negros em lojas virtuais de brinquedo representa 3\% do seu total (TERTO, 2016). Considerando que esse consumo será filtrado pelo poder aquisitivo e pelo gosto do indivíduo, não restam dúvidas de que bonecas que não são brancas e não são louras são poucas, se não nulas, e o acesso a elas é muito restrito, tornando-as excepcionalmente raras em sua recorrência e frequência.

Há uma diferença material grande entre as bonecas negras e as louras de olhos azuis: a maioria das bonecas negras não é industrializada, produzidas como contracultura em relação à sua ausência enquanto commodity, o que incrementa, por outro lado, produções artesanais que questionam hegemonias de consumo (DE CERTEAU, 2007). Basta perceber como são frequentes bonecas negras de pano. Nesse sentido, Luan e Luana são 
também exceções, pois são parte do mundo industrial, cujos materiais artificiais como plásticos e borrachas acompanham ideologias perpetuadas pela cultura material da estética hegemônica.

Figura 1 - Luana e Luan, próximos de seus 30 anos de idade (Foto do autor, 2019).

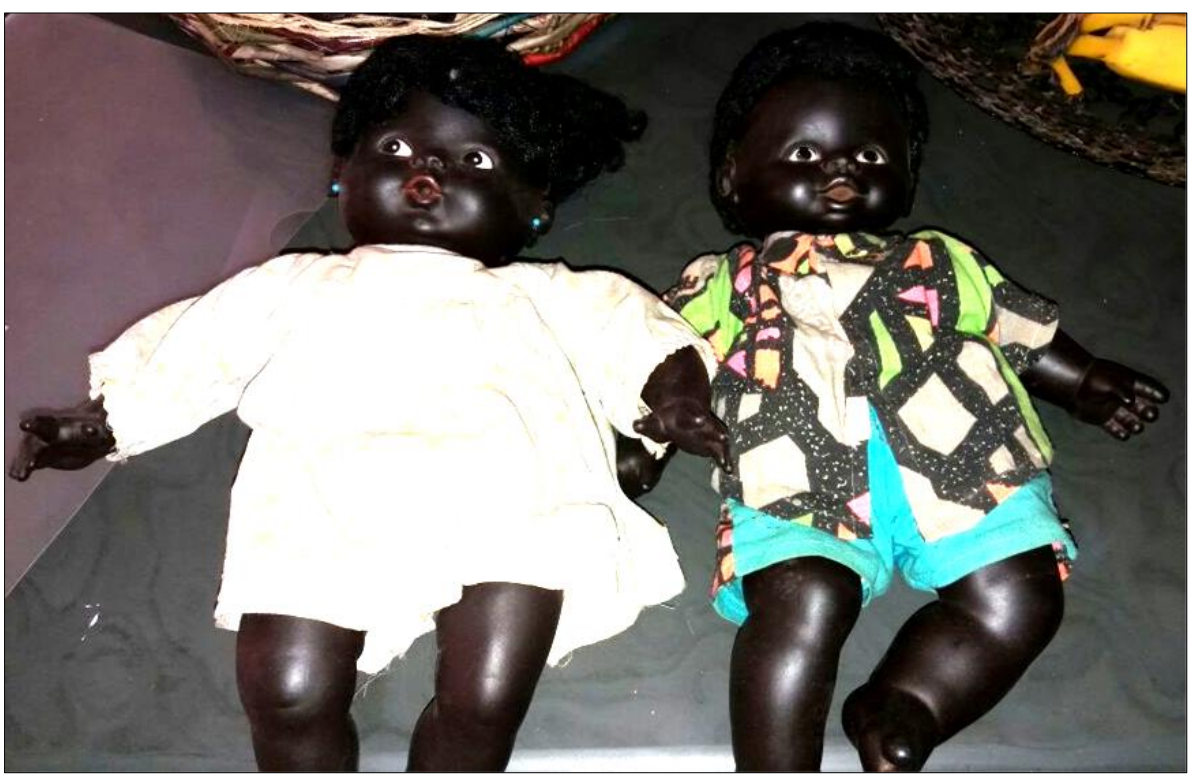

O cabelo é seguramente uma das materialidades que mais sofre, através de fortes objetificações racializadas, os efeitos do racismo, consequência de sua agência na concretização de posturas antirracistas e de autoafirmação, veículo de expressão e símbolo de resistência cultural que reabilita o corpo negro e reverte representações negativas (GOMES, 2008). Assim, o cabelo é evidentemente parte inerente da trajetória do corpo negro e do processo de submissão e controle que este sempre sofreu. Não é incomum que o cabelo e os penteados afro, como o dreadlock ou as tranças-nagô, sejam tachados de sujos, feios, associados a ideias higienistas e percepções que recuam às representações sobre o cabelo dos grupos escravos (ROSEMAN, 2017). No entanto pouco sobre cabelo, especialmente os afro, tem sido produzido sob a ótica arqueológica, também porque pouco dele sobrevive aos processos tafonômicos e decompositores após a morte.

Olhares arqueológicos sobre nossos cabelos poderiam abordar as narrativas de seus discursos materiais e as práticas em torno de sua materialidade. Depois de anos raspando a cabeça, por exemplo, usando bonés na escola e escondendo qualquer vestígio do meu cabelo, aos 21 resolvi usá-lo de outro modo, deixando-o crescer. Após tanto apagamento, eu já não conhecia mais o meu próprio cabelo. $\mathrm{O}$ boné foi o porto seguro à minha sensação de fora-do-lugar, que, por outro lado, invisibilizava parte importante do meu corpo através de um objeto cuja função presumida não era essa. Quanto mais eu crescia, menos podia usá-lo em sala de aula - afinal, para a professora, eu estava me protegendo do que?

Colegas perguntavam se podiam pôr a mão no meu cabelo, se eu havia feito algo nele ou se ele era mesmo daquele jeito. Era muito referido como cabelo "tonhonhóim", raramente como crespo ou enrolado, mais um eufemismo discriminatório. Diziam que podiam esconder lápis e outras coisas nele durante as aulas. Meu cabelo era equiparado a um local de armazenagem e descarte, para onde as coisas vão, mas não voltam, perdidas e fora da visão, como uma lixeira (WHEELER, 2000). Só mais tarde entendi que esse 
comportamento invasivo significava algo muito maior, ainda pior quando negritude e gênero se interseccionam.

É importante lembrar que não há diferença bioquímica entre os cabelos ditos afro e os demais tipos de cabelo, e a biologia humana tem mostrado que a diferença morfológica que se vê depende de sua secção transversal e de como cresce, da forma do folículo piloso e de sua posição no couro cabeludo (QUADFLIEG, 2003). Diferente da pele, a plasticidade do cabelo permite sua modelagem e a aquisição de diferentes texturas, cores e formas que revelam padrões estéticos e percepções de mundo. Mylene Mizrahi (2015, p. 31) chamou nossos cabelos de "ambíguos", por estarem sempre entre o implícito desejo do desfazer-se de uma identidade e do afastamento do gosto hegemônico branco. "Você não penteia o cabelo?" parte portanto de um pressuposto que desconsidera o cabelo crespo, colocando-nos sempre em uma posição negativa e expondo a ausência de uma prática que é considerada de alta valia e socialmente compartilhada - o pentear das madeixas.

A experiência de pessoas negras com seus cabelos começa muito cedo, e principalmente as mulheres passam por duros e constantes "rituais de manipulação" na infância (GOMES, 2002, p. 42). Já os homens, por outro lado, lidam com os cabelos eliminando sua existência física, os "raspando". Os processos de reconhecer e relembrar sua dimensão material são ainda mais dolorosos, pois sua materialidade é exotizada o tempo todo. O cabelo afro é objeto constante do toque não consentido, parte de um corpo que é frequentemente alvo de extrema curiosidade, racializado e sexualizado (CORREA, 1996). O cabelo, em seu papel social, projeta noções do eu, de pertencimento e de diferença, acompanhado dos objetos para sua manutenção e adorno, e dá concretude à identidade e apresentação aos outros (ALDHOUSE-GREEN, 2004; ASHBY, 2014).

Neste escopo, existem alguns artefatos que nos oprimem de modo muito sutil, apoiados nas preconcebidas referências depreciativas ao corpo negro. São aqueles objetos cujas associações em contexto os tornam commodities distintas do sentido para as quais foram pensadas quando fabricadas, relacionando cuidados-de-si a dolorosos processos de opressão estética. Desse modo, para uma arqueologia do racismo à brasileira, o pente é um desses fruidores: em um mundo de materialidades lisas, em que o pano de fundo é branco, a ausência das possibilidades de uso e não uso de certos objetos majoritariamente produzidos para encaixarem-se nos cabelos lisos está relacionada a uma fadada ausência de preocupação estética e higiene deste não consumidor. Assim, é comum que a frase "arrume esse cabelo" ou "penteie esse cabelo" esteja associada a toda uma tecnologia de asseamento que não apenas não é própria do corpo negro como força, sobre a materialidade dos cabelos crespos, coisas que lhe violentam, quebrando-os, arrancandoos e causando-lhes literalmente dor.

Eu não uso pente - nenhum pente - a não ser em situações específicas: no banho ou se quisesse fazer um black power, e a pergunta "mas você não vai pentear o cabelo?" nos trabalhos de campo partia, muitas vezes, de práticas do cuidado-de-si referentes aos cabelos lisos e suas cabeças brancas. Ela tinha como prerrogativa não só o desconhecimento de outros rituais de beleza como implicava na negativa de um comportamento e no possuir coisas consideradas saudáveis e universais, cujo oposto inferiria em posição decrescente na escala estética.

O boné é outro desses itens opressores: ao esconder os meus cachinhos na infância, uma das maiores violências cometidas contra mim era puxar meu boné à força e expor aquilo que eu queria tanto esconder: o meu cabelo. Fazê-lo era um ato cruel de humilhação pública, uma invasão a um lugar proibido do meu corpo, num ataque inesperado a uma região sensível. O boné foi um dos meus maiores símbolos de opressão e com ele construí uma relação ambígua e cíclica: ao usá-lo para esconder-me, carregava 
um indicativo de vergonha, pois o modo como o usava, dentro da sala de aula, sendo o único a fazê-lo, não se encaixava nem no que era esperado do boné nem da sala de aula. Ao fazê-lo, abria possibilidades para maiores humilhações, aumentando em mim o medo de ser visto. Todavia deveria continuar usando-o, pois não queria que o meu cabelo fosse olhado e nem que fosse alvo de chacotas. Era uma espécie de síndrome de Estocolmo construída com um objeto que incrementava o racismo agudo que me assolava - eu precisava de algo que me feria.

Esse exemplo pessoal permite enveredar por duas vias complementares. A primeira é a do consumo como cultura material (MILLER, 2007). Se o consumo é um importante marcador e construtor de identidades, a ausência de consumo ou a ausência do que consumir diz muito. Como pontua Livio Sansone (2000, p. 88), proibições em relação ao consumo desde a escravidão destinavam-se a desumanizar e a marcar a exclusão, haja vista a negação do uso de sapatos aos escravos e seu uso como marcador da alforria e prática de humilhação (CUNHA, 1988, p. 23; LIMA, 2008). Em sociedades de base racista como a nossa, o consumo pode atuar como marcador identitário, como forma de oposição à opressão e modo de ser visto ou ouvido (SANSONE, 2000). Seu oposto, o não consumo, portanto, dá foco à falta e a presente ausência da materialidade atuando como forma de opressão. É claro que eu queria, comprei e tentei usar pentes, dividir o meu cabelo no meio. E é claro que não deu certo. Mas a questão não pode pautar-se apenas por uma análise do tipo presença/ausência.

Há que se considerar uma segunda via, a da forma e função da ergonometria na cultura material: a maioria dos pentes, como eram e como ainda são, impõe que o corpo negro se adapte à sua agência opressiva e violenta, uma vez que eles só penteiam um determinado tipo de fio; por outro lado, a falta de objetos cuja forma vai de encontro ao cabelo crespo é um forte marcador de exclusão. São diversos os pentes, mas nenhum serve. Isso aumenta o peso da marginalização de toda uma população pela negação dos benefícios da modernidade, como o uso de pentes plásticos, que submete essa população a um sistema de hierarquias de cabelo que solidifica a sensação do "tem algo de errado comigo". Se não eliminada, a materialidade do cabelo afro passa a ser parte da própria construção material da identidade individual, mas também expressão de uma identidade coletiva visivelmente questionadora das normatividades da beleza eurocêntrica, por sua própria existência.

A racialização desse cabelo passa, desse modo, pela montagem de toda uma tecnologia para alterá-lo, escondê-lo ou destruí-lo, em processos que são verdadeiras rupturas materiais em sua forma, dimensão, cor, textura e tratamento: categorias discriminantes e discriminatórias. Esses processos são lembrados com dor, como no caso de memórias de alisamento, do uso de pentes finos e dos bonés para invisibilizá-los.

As distintas narrativas construídas a partir da associação contextual entre objetos, entre objetos e corpos e entre corpos tende a pender negativamente para o nosso lado, como no uso do boné, exemplo do ônus material da negritude. É claro que em sociedades com forte opressão de classe, raça e gênero como a brasileira, os objetos ganham, produzem e replicam significados repressivos no cotidiano. A diferença que eles expressam frequentemente é apropriada e ressignificada sob a marca da desigualdade, da exploração e da opressão (SILLIMAN, 2005). Um exemplo disso foi quando eu e um amigo nos vestimos exatamente com os mesmos modelos de roupa branca para o Ano Novo, eu fui associado a um pai de santo e ele a um médico, mais um comentário pautado por hierarquias discriminatórias. Essa oscilação nos sentidos que as coisas projetam fazem delas um importante mediador de relações sociais em contextos de racismo à brasileira. Me refiro, assim, ao papel da cultura material como taxativa do preconceito quando sobreposta a corpos e sujeitos específicos. 
Recorro à outra lembrança: ao redor dos 10 anos de idade, em meio ao Plano Collor, após o bloqueio das poupanças privadas, alguns supermercados passaram a dar descontos se trocados lixos recicláveis por alimentos. Saíamos então para catar latas de alumínio nas lixeiras das ruas em momentos nos quais a inflação do dia variava em até $300 \%$. A diversão era achar mais latinhas. Lembro-me da sensação do resto de refrigerante escorrendo entre meus dedos e do cuidado para não me cortar. Quando havia restos de comida grudados na latinha, não queria pegar. Ao final, a brincadeira também era pisar nas latas para transformá-las em disquinhos, apesar de o supermercado dispor de amassadores mecânicos, para que ocupassem menos espaço. Lembro-me também de como o supermercado impediu minha passagem dos amassadores as prateleiras.

Nesse caso, se como criança o universo se abria em um mundo de possibilidades materiais associados ao brincar, era o ato de ressocializar objetos descartados que me colocava em um lugar esperado, subalternizado, único (RIBEIRO, 2019) já que não mais praticava a lógica burguesa e circular de compra-descarte-compra do consumismo moderno. Se as lixeiras significam escoadouros do que não mais se quer ver/ter para uns, elas se abrem como locais de armazenamentos conhecidos e mapeados dos quais as coisas podem voltar à vida para outros. Apesar do contexto de empobrecimento generalizado, a reciclagem invertia as lógicas mercantis de aquisição de objetos visando o lucro por meio da compra, e reciclar atuava como tática criativa-alternativa em uma situação obviamente difícil (GONZALEZ-RUIBAL, 2006, p. 176). Apesar disso, concretizava espaços segregados, as prateleiras do mercado como materialidades oposta às do meu lugar único, o dos amassadores.

\section{PAISAGEM, DESAPARECIMENTO E NEGRITUDE}

A associação entre cultura material e corpo negro, meio ao racismo à brasileira, serve, portanto, para concretizar marcadores de negritude por meio de práticas, de comportamentos racializados e da opressão racista que relaciona objeto, grupo social e estereótipo. Isso tem alcançado dimensões terríveis, em especial ao homem (jovem) negro em sua relação com as forças de segurança. No âmbito de uma arqueologia do lugar como a que propõe Maria Zedeño (1997, p. 73), ao somarem-se paisagem (a da periferia), coisas (o boné, o chinelo de dedo, as latas) e recursos (pobreza), consolidam-se territórios racializados como objetos discriminatórios agregados.

Essa combinação nos torna alvo de operações policiais taxativas de uma população perigosa, porque de baixa renda, porque negra, porque moradora da periferia, porque de cabelos crespos e potencialmente criminosa. Ao passar por postos de controle policial, por exemplo, a maioria das pessoas autoidentificadas brancas talvez não saiba da ritualística, passada de uma geração à outra, que envolve a cultura material e que deve ser religiosamente respeitada: tirar o boné, os óculos escuros, desligar a música, calçar os sapatos e acender a luz. No Brasil, as blitz são espaços de insegurança e volatilidade no qual o Estado decide se nosso corpo negro e nossas coisas tem direitos para passar ou se devem ser separados dos demais cidadãos (RIZVI, 2013, p. 495).

A dimensão material associada à negritude, opressora ou libertadora, escondendo ou valorizando traços, nos marca como alvo e tem relação com os dispositivos de desaparecimento utilizados pelo Estado no âmbito da construção de "classes perigosas" e da personificação do mal que se quer eliminar porque vai contra o modelo de cidadão que se quer impor. A necessidade de controlar e dominar um entorno objetificado passa pela elaboração do medo e pelo processo de construção cultural desse mal, como sugere Michael Taussig (1984). Potencialmente maus e temidos, judeus, negros, mulheres, comunistas, feministas, gays, travestis ou indígenas, ao questionarem ordem 
hegemônicas, tornam-se objetos de desprezo, mas, ainda assim, admirados, já que é preciso incluir para excluir e oprimir (TAUSSIG, 1984, p. 470).

A produção de narrativas sobre o corpo negro e suas associações com espaços e objetos como concretização do mal e do medo que deve ser eliminado materializa dispositivos que possibilitam o uso do desaparecimento como estratégia focada em biotipologias que constrói um indivíduo como sendo de alta periculosidade. A paisagem, ordenada por higienismos sociais que nos expulsam para lugares distantes e isolados e criam leis que precarizam situações e tornam o cotidiano inseguro (PRADA, 2018, p. 33), cunham cenários perfeitos para execuções e desaparições, para a submissão da vida pela morte - ao que Achille Mbembé (2018) chamou de necropolíticas. É o caso dos "atos de resistência”, justificativas legais por meio dos quais a Polícia Militar explica a morte violenta de pessoas negras, alegando legítima defesa frente às alegadas resistências à prisão. Tais dispositivos recorrem nas infraestruturas estatais e remontam ao regime militar, quando da implantação de doutrinas de segurança nacional - aquelas fundamentadas em justificativas de proteção da sociedade (PADRÓS, 2012, p. 46).

A segregação espacial e social do corpo negro no Brasil é muito evidente. A morte e o encarceramento em massa de corpos negros já não causam espanto, o falecimento e a prisão como lugares e paisagens esperadas para nós, o que Lélia González (1982) chamou de "lugar do negro". O mesmo ocorre quando estamos presentes em locais como shoppings, universidades e ruas de determinados bairros, onde, pelo contrário, não somos esperados, onde nossa ausência é naturalizada e inquestionada (BORGES, 2019). O que vem sendo chamado de genocídio PPP - da população "pobre, preta e periférica" - é o exemplo maior da relação entre espaço, cultura material e recursos, concretizando lugares e paisagens racializadas que perpetuam o racismo a partir da eliminando física de nossa própria materialidade.

Por isso arqueologias da arquitetura, do fechamento ou da paisagem do racismo à brasileira têm potência ao mostrar sua institucionalidade por meio da reprodução de estruturas que subjazem a cor da pele como parâmetro de sociabilidade através da concretude do espaço e de discursos materiais que naturalizam o racismo como o normal da vida social (ALMEIDA, 2018). Processos como o do desaparecimento tem dimensão material fundamental que merece leituras arqueológicas. No Brasil, as estruturas judiciais e investigativas do Estado são exemplo dessa situação, em especial devido à herança criminológica de suas engrenagens. Nesse âmbito, nossa medicina legal foi chave na definição científica do racismo na primeira metade do século XX e em sua perpetuação estrutural até hoje.

Resquícios de uma antropologia criminal racializada (PENA, 2005) ainda sobrevivem nas práticas que subjazem processos investigativos e forenses em nefastas relações entre corpos desconhecidos, objetos associados, lugar e população marginal enquanto materialidades discriminatórias (ANUNCIAÇÃO et al., 2020). É o caso dos Crimes de Maio de 2006, que, num intervalo de oito dias, resultou na morte e desaparecimento coordenado de 564 pessoas majoritariamente negras em bairros racializados do estado de São Paulo (BRITO, 2016). O sistema de estruturas físicas que deveria zelar pela materialidade do corpo após a morte no Brasil permite a perda e o apagamento de identidades pela falta de traçabilidade entre instituições (os chamados desaparecimentos administrativos) (CARNEIRO, 2019). Essa arquitetura é a mesmo que associa corporalidade à indigência e crime, reduzindo o valor de nossos corpos mortos - "era indigente", como se a categoria justificasse sua dessacralização e invalidasse sua relação com pessoas desaparecidas (TELES, 2015).

Outro exemplo que associa materialidade e narrativas aos efeitos concretos do racismo é a coleta sistemática de cédulas de identidade e pertences pessoais, construtores 
de identidades sociais e parte das poucas coisas que dão forma a sua vida privada, da população em situação de rua. Todo um aparato material está envolvido na genealogia desse apagamento e em tornar tal população ainda mais vulnerável aos dispositivos de desaparecimento. Caminhões-caçamba coletam camas, papelões, bolsas e toda vida material dessas pessoas em um longo processo de desmaterialização que, ao final, garante que, se mortas, acabarão com seus corpos desaparecidos ou tornados desconhecidos pelas próprias estruturas policiais do Estado (como a médico-legal).

Sem documentos e sem pertences pessoais, os moradores de rua são despersonalizados e desmaterializadas de modo sutil, a la racismo à brasileira, no interior do próprio sistema que deveria cuidar deles (PEIRANO, 1986). Esse racismo estende, assim, suas consequências nefastas aos que não se submetem ou não se encaixam na ordem hegemônica e na paisagem racista que se quer ver mesmo depois da morte, em estratégias de ocultação de corpos igualmente perspicazes e que têm sido entendidas como formas de necrogovernabilidade (FRANCO, 2018). A eliminação material de nossa existência dá origem a paisagens de terror que, por outro lado, se materializam pela frequência com que nossa própria materialidade está ausente.

\section{ARQUEOLOGIAS AMEFRICANAS}

A realidade parece inexorável. O racismo constitui nossa realidade e é pano de fundo tanto da relação dos arqueólogos entre si como de seu pensamento arqueológico. Não há clara escapatória enquanto o sistema capitalista imperar com sua necessidade intrínseca de classificar indivíduos e subalternizá-los através da racialização de nossas diferenças físicas e da contextualização racista da materialidade que nos cerca (SPIVAK, 2010). Isso dá muita raiva. E a raiva, não o ódio, é um ótimo combustível a mudanças. Mas devemos recorrer a raivas especificas. Em meu caso, pautando-me nas propostas de Maria Lugones (1995, p. 110), troquei a raiva que me fez chorar aos seis anos, a da indignação de ter sido tratado injustamente, ingenuamente pedindo para ser ouvido pela mesma sociedade que me silenciava, pela que move contra opressões institucionalizadas. Esta raiva, sim, incentiva o rebelar-se, dando voz às injustiças não reconhecidas pelas estruturas convencionais.

Tal raiva lança a semente da reivindicação por representatividades a partir de lugares de fala em meio a normatizações hegemônicas (RIBEIRO, 2017, p. 43). Este texto, por exemplo, foi escrito após comentário piadista sobre o fato de que, por causa da minha cor, era eu, dentre três - outras pessoas que não possuíam os marcadores físicos da negritude, quem deveria jogar o lixo fora - minha bioculturalidade mais uma vez associada ao lixo.

A materialidade do racismo precisa ser criticamente abordada pela arqueologia, não apenas no âmbito de sua história, da formação do campo discursivo e dos usos do passado, mas como ocorre no dia a dia da prática científica, considerando as coisas como parte de sua dimensão concreta. A ausência desse tema na arqueologia brasileira ecoa o desafortunado sucesso do mito da democracia racial e da falácia da inexistência do racismo no Brasil. Apesar de importantes trabalhos em torno da arqueologia da escravidão e da diáspora africana no país, o racismo como tema ainda é pouco corrente, como apontou Lara Passos (2019). Do mesmo modo são as análises de sua dimensão material e da materialidade de sua opressão.

Entretanto a arqueologia brasileira vive profundos momentos de transformação. Sua abertura a novas temáticas e às possibilidades de questionamentos das normatividades por meio de posturas decoloniais, feministas, queer e anarquistas tem tecido críticas a materialidades inconspícuas, permitindo a ela atuar também como um modo de ver e viver o mundo (RIBEIRO, 2017). O século XXI assistiu à abertura dos 
cursos de graduação em arqueologia nas regiões Norte e Nordeste, por exemplo, os quais parecem ter tido enorme impacto no quadro étnico-racial, socioeconômico e demográfico que dominava a arqueologia elitista e branca sul-sudestina até então, também graças à implementação dos sistemas de cotas nas universidades públicas.

Essa transformação da arqueologia tem vindo como afirmação da negritude enquanto contraponto ao racismo em sua dimensão concreta, nos objetos que o materializam e nas expressões de sua corporalidade. Como lembra Kabengele Munanga (POMPEU; MUNANGA, 2017), enquanto houver discriminação pela cor da pele, esta afirmação será necessária. Aproximar a experiência da escravidão de nossa própria é outro modo. É frequente que o incômodo ao visitar locais do holocausto judeu não ocorra na visita a senzalas, por exemplo. Eu mesmo só senti essa proximidade quando ouvi minha avó usar expressões como "nascido de ventre livre" em plenos anos 2000. O fim da escravidão foi ontem e por isso a arqueologia do racismo é uma arqueologia do passado contemporâneo.

Engajar pessoas, comunidades e movimentos sociais na interpretação, construção da memória e patrimonialização são outros caminhos importantes para afirmações positivas da negritude (CICALO, 2013). Projetos de arqueologia que trabalhem a temática podem ter impactos inesperados e difíceis de mensurar, e menciono aqui alguns que tiveram enorme impacto pessoal em minha identidade e autoestima. $\mathrm{O}$ primeiro foi $\mathrm{o}$ projeto do Valongo, no porto do Rio, que teve à frente Tania Andrade Lima, trazendo à tona narrativas sobre o porto negro e a Gamboa (LIMA, 2013), e com o qual não tive qualquer envolvimento direto. A começar porque meu bisavô e meu avô negros trabalharam na área portuária por décadas, entre os anos 1930 e 1980. Tive também uma apropriação imediata dos seixos encontrados nas escavações arqueológicas (SYMANSKI, 2014; CARNEIRO, 2015), os otás e sua forte agência, já que cresci com eles. Seus sentidos para mim estavam claros: amuletos que protegem e trazem boa sorte, que, quando de rios, se ligam ao mito da criação da cachoeira, como um ponto de força e, portanto, de contato com meus orixás.

Outro projeto sobre o tema e que teve grande impacto pessoal, o maior dentre todos talvez, foi o do sítio arqueológico da praia do Sahy, em Mangaratiba, ainda no estado do Rio, coordenado por Camila Agostini (2015) que se debruçou sobre a relação entre negros, indígenas e seus descendentes em torno das ruinas ligadas ao tráfico ilegal de escravizados. O local foi também um antigo porto, mas clandestino. Ele acionou curiosidades sobre uma parte pouco conhecida de minha própria história familiar, a de descendente de indígenas e africanos da região. $\mathrm{O}$ tema intensificou diversos laços intrafamiliares através de conversas em torno dele: fotos, lembranças, encontros, amigos, coisas, territórios, lugares e experiencias negras ressurgiram, silêncios foram preenchidos, mas também se abriram.

Ambos os projetos materializaram experiências soterradas, tidas como óbvias demais e muito singulares para serem partilhadas, reprimidas pelo receio da discriminação sabida, pois desvalorizadas socialmente, parte de processos históricos que não são nada únicos. Similares prerrogativas estão presentes na arqueologia dos candomblés conduzida por Rodrigo Pereira focado na valorização de matrizes afrobrasileiras ao debater sobre a dimensão material da religiosidade, sobre processos de construção da paisagem do candomblé na cidade do Rio e sobre microhistórias desenroladas na vivência dos terreiros (PEREIRA, 2014; PEREIRA; CHEVITARESE, 2019).

Ressaltando elementos culturais e linguísticos afro-ameríndios em grupos não hegemônicos, os projetos supracitados são arqueologias "amefricanas" ou "afro-latinoamericanas", inspirando-me em Lélia González (1988, p. 76). Arqueologias amefricanas 
reconhecem o caráter multirracial e pluricultural das sociedades e estruturas que mantêm subordinados negros e indígenas. Engolfam tanto a diáspora negra quanto o extermínio indígena e constroem arqueologias de resistência, rebelião e luta (ORSER; FUNARI, 2004) enquanto "mecanismos estratégicos de visibilidade" (CARDOSO, 2014). Esses projetos dão importância a meu mundo e ao de milhares de pessoas, no sentido de que tais dimensões materiais, a dos africanos, seus descendentes, suas experiências e legados, importam. Elas interessam a alguém que fala de estruturas de poder como a universidade, ou mesmo o poder público. Vale que nós negros pensemos mais frequentemente o quanto nos sentimos presentes nas histórias construídas por projetos arqueológicos ou se os sujeitos por eles abordados serão sempre os da alteridade.

\section{CONSIDERAÇÕES FINAIS}

Neste artigo, quis tecer comentários sobre a materialidade do racismo, sobre como ela concretiza arcabouços de discriminação de modo silencioso via consumo, representação e corporalidade, e sobre como a arqueologia pode materializar a aceitação de nossa negritude, passo fundamental para a construção de "modelos diversos de autoestima” (SCHWARCZ, 2012, p. 85). Essa arqueologia deve ser, portanto, de combate, chamando atenção para como o conhecimento é situado na gama de contextos diferenciados nos quais a ciência ocorre (HARAWAY, 1988, p. 591). Como arqueologia de combate, ela permite a abertura de espaços de representatividade e o reforço a lugares de fala aos descendentes da diáspora africana, historicamente diminuídos, excluídos e avexados, no que Carl Hasenbalg (1979, p. 220) chamou de "ciclos de desvantagens cumulativas".

A arqueologia pode se alinhar à luta antirracista escancarando o racismo à brasileira ao longo da nossa história (quantos pentes como os mencionados aqui existem pelos registros arqueológicos país afora?) - reconhecendo os privilégios gradativos e proporcionais à quantidade de traços da estética/fenótipo branco (a diferença no aparato material de casas de operariados negros denota sistemas de privilégio pela exclusão das possibilidades de consumo?) - , e instigando a crítica ao racismo silencioso e pessoal (o quanto reproduzimos dessa ideologia nas práxis de nosso próprio campo de estudos?). De fato, sou mais parecido fisicamente com os chamados "auxiliares de campo" ou "trabalhadores" do que a maior parte de meus colegas de profissão.

O racismo à brasileira acontecerá atrelado à pele, mas também à cultura material que me acompanha: boné, pente, boneca, seixos, latinhas são definitivamente polifônicos, mas as narrativas construídas ao redor deles por ideologias hegemônicas não são as que necessariamente fazem bem. Não gostaria que meus colegas arqueólogos chamassem meus seixos de "macumba". Como arqueólogas e arqueólogos, e no âmbito da arqueologia, não devemos aceitar: revolte-se, denuncie. Deixe o racismo sem jeito, chame atenção para o absurdo. Chame atenção aos modos materiais de sua concretude em nossas vidas, da materialização de sua obviedade. Usemos os questionamentos da arqueologia contra seus próprios discursos. Busquemos arqueologias antidogmáticas e marginais (AMORIM; NOGUEIRA, 2015) que pensem o racismo e incentivem construções de perspectivas arqueológicas afrolatinoamericanas. Ampliemos projetos e temas, representatividades e espaços a lugares de fala.

Diversificar abordagens enriquece temáticas: falas advindas de outras identidades permitem a elaboração de perguntas diferentes com base em perspectivas distintas (BATTLE-BAPISTE, 2011, p. 21): quantos otás devem ter sido descartados em campos por aí afora? O sistema de cotas tem sido um apoio fundamental. Problematizemos as equipes de campo, as trajetórias individuais, a ausência de grupos sociais específicos. Dados seriam interessantes e precisamos nos compreender melhor como campo 
científico. Quais são as estruturas que encorajam ou desencorajam a participação, na arqueologia, de minorias (APPADURAI, 2009; AGBE-DAVIES, 2012, p. 27)? Na sociedade de arqueologia brasileira, quantos não se autodeclaram brancos?

A arqueologia pode ser um espaço criativo e excepcional pelos benefícios públicos que traz a comunidades subalternizadas e grupos marginalizados, dos quais alguns de nós arqueólogos somos parte, em especial pelo olhar único à dimensão material de nossas vidas. Podemos nos unir às outras ciências sociais e biológicas no combate ao racismo, quebrando as barreiras racialmente alicerçadas que existem na vida social (MCDAVID, 2010, p. 44). Representatividade importa. Materialidade também. O que de fato estamos fazendo para mudar a realidade que nos incomoda? Como fazemos uma arqueologia que contribui e é de fato relevante para os problemas que afligem o mundo contemporâneo? Racismo é crime. Nos oprime, mata e desaparece.

\section{AGRADECIMENTOS}

Agradeço à Camila Agostini e aos alunos do curso de graduação em Arqueologia da Universidade Estadual do Rio de Janeiro pela leitura atenta e comentários ao texto. 


\section{REFERÊNCIAS BIBLIOGRÁFICAS}

AGBE-DAVIES, Angela S. Black scholars, black pasts. The SAA archaeological record, v. 2, n. 4, p. $24-28,2012$.

AGOSTINI, Camilla. (org.) Objetos da escravidão. Abordagens sobre a cultura material da escravidão e seu legado. Rio de Janeiro: 7Letras, 2013.

AGOSTINI, Camilla. Relatório Anual de Pesquisa Arqueológica IPHAN. Projeto: Os africanos não estavam sós. Relações entre grupos não hegemônicos no litoral sul-Etapa 1 - Mangaratiba. Rio de Janeiro: UERJ, 2015. Disponível em: www.labhoi.uff.br/repair/ppp/pdf/Relatorio\%20IPHAN\%201\%20ano_2014.pdf. Acesso em 06 dez. 2019.

AGOSTINI, Camilla. Temporalidades e saberes inscritos em ruínas e memórias. Vestígios, v. 13, n. 1, p. 29-50, 2019.

ALDHOUSE-GREEN, Miranda. Crowning glories: languages of hair in later prehistoric Europe. Proceedings of the Prehistoric Society, n. 70, p. 299-325, 2004.

ALMEIDA, Silvio Luiz de. O que é racismo estrutural? Belo Horizonto: Letramento, 2018.

AMORIM, Tomaz; NOGUEIRA, Renato. Afroperspectividade: por uma filosofia que descoloniza. Negro Belchior, 2015. Disponível em: http://negrobelchior.cartacapital.com.br/afroperspectividade-por-uma-filosofia-quedescoloniza/. Acesso em 11 ago. 2017.

ANUNCIAÇÃO, Diana; TRAD, Leny A. B.; FERREIRA, Tiago. "Mão na cabeça!": abordagem policial, racismo e violência estrutural entre jovens negros de três capitais do Nordeste. Saúde e Sociedade, v. 29, n. 1, e190271, 2020.

APPADURAI, Arjun. O medo do pequeno número: ensaio sobre a geografia da raiva. São Paulo: Iluminuras, 2001.

ASHBY, Steven P. Technologies of appearance: hair behaviour in early Medieval Europe. Archaeological Journal, v. 171, n. 1, p. 151-184, 2014.

BABSON, David W. The archaeology of racism and ethnicity on southern plantations. Historical Archaeology, v. 24, n. 4, p. 20-28, 1990.

BAL, Aydin. System of disability. Critical Education, v. 8, n. 6, p. 1-27, 2017.

BARETTA, Jocyane. Arqueologia da repressão e da resistência e suas contribuições na construção de memórias. Revista de Arqueologia Pública, v. 8, n. 2, p. 76-89, 2017.

BATTLE-BAPTISTE, Whitney. Black feminist archaeology. Walnut Creek: Left Coast Press, 2011.

BORGES, Juliana. Encarceramento em massa. Belo Horizonte: Letramento, 2019.

BRITO, Gisele. Crimes de Maio: 10 anos. Brasil de Fato, 2016. Disponível em: https://www.brasildefato.com.br/2016/05/13/surgido-da-dor-maes-de-maio-se-tornamreferencia-no-combate-a-violencia-do-estado/. Acesso em 15 mai. 2019.

BUCHLI, Victor; LUCAS, Gavin. (ed.) Archaeologies of contemporary past. Londres: Routledge, 2001.

CAMINO, Leôncio; SILVA, Patrícia; MACHADO, Aline; PEREIRA, Cícero. A face oculta do racismo no Brasil: uma análise psicossociológica. Revista de psicologia política, v. 1, n. 1, p.1336, 2001.

CARDOSO, Cláudia Pons. Amefricanizando o feminismo: o pensamento de Lélia Gonzalez. Revista Estudos Feministas, v. 22, n. 3, p. 965-986, 2014.

CARLE, Cláudio; SANTANA, Ingrid A. S. F.; OLIVEIRA, Cícero N. P. As cumplicidades racistas da arqueologia. Revista de Arqueologia Pública, v. 12, n. 2, p. 1-19, 2018. 
CARNEIRO, Eliana F. V. O Ministério Público e os Serviços de Verificação de Óbito: a urgente necessidade de fiscalização desse serviço público em prol das pessoas desaparecidas ou da materialidade de delitos. In: MPF. (org.) O Ministério Público e o Controle Externo da Atividade Policial, v. 2. Conselho Nacional do Ministério Público. Brasília: CNMP, 2019. p. 30-44.

CARNEIRO, Sandra de Sá; PINHEIRO, Márcia Leitão. Cais do Valongo: patrimonialização de locais, objetos e herança africana. Religião e Sociedade, v. 35, n. 2, p. 384-401, 2015.

CARVALHO, José J. O confinamento racial do mundo acadêmico brasileiro. Revista USP, v. 68, p. 88-103, 2005-2006.

CHIN, Elizabeth. Feminist theory and the ethnography of children's worlds: Barbie in New Haven, Connecticut. In: SCWARTZMAN, Helen B. (ed.) Children and anthropology: perspectives for the 21st century. Westport (Connecticut/EUA): Bergin \& Garvey, 2001. p. 129-148.

CICALO, André. A voice for the past: making 'public' slavery heritage in Rio de Janeiro. International Journal of Tourism Anthropology, v. 3, n. 2, p. 170-183, 2013.

CORREAA, Mariza. Sobre a invenção da mulata. Cadernos Pagu, v. 6-7, p. 35-50, 1996.

CORSO, João C. Aproximações entre Arqueologia e o estudo dos movimentos sociais contemporâneos: MST e CPT. Vestígios, v. 4, n. 2, p. 69-87, 2010.

CUNHA, Manuela C. Olhar escravo, ser olhado. In: AZEVEDO, Paulo C.; LISSOVSKY, Maurício. (org.) Escravos brasileiros do século XIX na fotografia de Christiano Jr. São Paulo: ExLibris, 1988. p. 23-30.

CURTONI, Rafael P.; POLITIS, Gustavo G. Race and racism in South American archaeology. World Archaeology, v, 38, n. 1, p. 93-108, 2006.

DAMATTA, Roberto. Digressão: a fábula das três raças, ou o problema do racismo à brasileira. In: DAMATTA, Roberto. Relativizando, uma introdução à antropologia social. Rio de Janeiro: Rocco, 1990. p. 58-87.

DE CERTEAU, Michel. A invenção do cotidiano. Petrópolis: Vozes, 2007.

DELEUZE, Gilles; GUATARRI, Félix. Mil platôs: Capitalismo e Esquizofrenia. Rio de Janeiro: Editora 34, 1995.

ECHO-HAWK, Roger C.; ZIMMERMAN, Larry J. Beyond Racism: Some Opinions about Racialism and American Archaeology. The American Indian Quarterly, v. 30, n. 3-4, p. 461-485, 2006.

ELY, Guilherme. A saudosa fábrica de brinquedos gaúcha. Gauchazh, Almanaque, 2017. Disponível em: https://gauchazh.clicrbs.com.br/cultura-e-lazer/almanaque/noticia/2017/10/a-saudosafabrica-de-brinquedos-gaucha-cj8nkuffm024c01 mqwjqglqah.html. Acesso em 11 abr. 2019.

FANON, Franz. Pele negra máscaras brancas. Salvador: Edufba, 2008.

FERREIRA, Lucio M. Vestígios de civilização: a arqueologia no Brasil Imperial (1838-1877). Dissertação (Mestrado em História) - Instituto de Filosofia e Ciências Humanas, Universidade Estadual de Campinas, Campinas, 2002.

FERREIRA, Lucio M. Sobre o conceito de arqueologia da diáspora africana. Métis, v. 8, n. 16, p. 267-275, 2009.

FONSECA, Dagoberto J. Você conhece aquela? A piada, o riso e o racismo à brasileira. São Paulo: Selo Negro, 2012.

FOUCAULT, Michel. Sobre a história da sexualidade. In: FOUCAULT, Michel. Microfísica do poder. Rio de Janeiro: Graal, 1998. p. 243-276.

FRANCO, Fábio L. Da biopolítica à necrogovernabilidade: um estudo sobre os dispositivos de desaparecimento Brasil. Tese (Doutorado em Filosofia) - Faculdade de Filosofia, Letras e 
Ciências Humanas, Universidade de São Paulo, São Paulo, 2018. doi: 10.11606/T.8.2019.tde25022019-112250.

FUNARI, Pedro P. A arqueologia e a cultura africana nas Américas. Estudos Ibero-Americanos, v. 16, n. 2, p. 61-71, 1991.

GARCIA, Roosevelt. Grandes fabricantes de brinquedos que fecharam as portas. Blog Memória - Veja São Paulo, 2017. Disponível em: https://vejasp.abril.com.br/blog/memoria/grandesfabricantes-de-brinquedos/. Acesso em 20 jun. 2020.

GOMES, Nilma L. Sem perder a raiz: corpo e cabelo como símbolos da identidade negra. Belo Horizonte: Autêntica, 2008.

GOMES, Nilma L. Trajetórias escolares, corpo negro e cabelo crespo: reprodução de estereótipos ou ressignificação cultural? Revista Brasileira de Educação, v. 21, p. 40-51, 2002.

GONZALEZ, Lélia. O movimento negro na última década. In: GONZÁLEZ, Lélia; HASENBALG, Carl. (ed.) Lugar de negro. Rio de Janeiro: Marco Zero, 1982. p. 9-66.

GONZALEZ, Lélia. Por um feminismo afrolatinoamericano. Revista Isis Internacional, v. 9, p. 133 $141,1988$.

GONZÁLEZ-RUIBAL, Alfredo. The past is tomorrow. Towards and Archaeology of the vanishing past. Norwegian Archaeological Review, v. 39, n. 2, p. 110-125, 2006.

GONZÁLEZ-RUIBAL, Alfredo. Hacia otra arqueología: diez propuestas. Complutum, v. 23, n. 2, p. 103-116, 2012.

GONZÁLEZ-RUIBAL, Alfredo. An Archaeology of the Contemporary Era: the Age of Destruction. Londres: Routledge, 2016.

GONZÁLEZ-RUIBAL, Alfredo; HERNANDO, Almudena. Genealogies of destruction: an archaeology of the contemporary past in the Amazon forest. Archaeologies, v. 6, n. 1, p. 5-28, 2010.

GRAVES-BROWN, Peter. Touching from a distance: alienation, abjection, estrangement and archaeology. Norwegian Archaeological Review, v. 44, n. 2, p. 131-144, 2011.

GUIMARÃES, Antônio S. Preconceito de cor e racismo no Brasil. Revista de Antropologia, v. 47, n. 1, p. 9-43, 2004.

HARAWAY, Donna. Situated knowledges: the science question in feminism and the privilege of partial perspective. Feminist studies, v. 14, n. 3, p. 575-599, 1988.

HARRISON, Richard; SCHOFIELD, John. Archaeo-Ethnography, Auto-Archaeology: Introducing Archaeologies of the Contemporary Past. Archaeologies, v. 5, n. 2, p. 185-209, 2009.

HASENBALG, Carl. Discriminação e desigualdades raciais no Brasil. Rio de Janeiro: Graal, 1979.

JOYCE, Rosemary. Archaeology of the body. Annual Review of Anthropology, v. 34, p. 139-158, 2005.

LEMES, Conceição. Para ativista, boneca da Estrela fere dignidade das crianças negras. Forum, 2015. Disponível em: https://www.revistaforum.com.br/para-ativista-boneca-da-estrelafere-dignidade-das-criancas-negras/. Acesso em 20 jul. 2020.

LEONARDO, Zeus. Race, whitness and education. Nova York: Routledge, 2009.

LIMA, Tânia A. Los zapateros descalzos: arqueología de una humillación en Rio de Janeiro del siglo XIX. In: ACUTO, Félix; ZARANKIN, Andrés. (org.) Sed non satiata II: acercamientos sociales en la arqueología latinoamericana. Buenos Aires: Encuentro, 2008. p. 33-55.

LIMA, Tânia A. Arqueologia como ação sociopolítica: o caso do cais do Valongo, Rio de Janeiro, século XIX. Vestígios, v. 7, n. 1, 2013, p. 179-207. 
LUGONES, Maria. Hard-to-handle anger. In: BELL, Linda; BLUMENFELM, David. (org.) Overcoming Racism and Sexism. Lanham (Maryland/EUA): Rowman \& Littlefield Publishers, 1995. p. 203-217.

MARQUES, Gabriel. Da Senzala a Unidade Racial: uma abordagem do problema racial no Brasil. Brasília: Planeta Paz, 1996.

MARTIN, Anthony. Toys with Professions: Racialized Black Dolls, 1850-1940. Journal of African Diaspora Archaeology and Heritage, v. 3, n. 2, p. 137-158, 2014.

MARTIN, Anthony. A list of racialized black dolls: 1850-1940. African Diaspora Archaeology Newsletter, v. 15, p. 1-65, 2015.

MARTINS, Leandra R. Perfil racial dos docentes da USP analisa baixo índice de professores negros. AUN - Agência Universitária de Notícias, 2017. Disponível em: https://paineira.usp.br/aun/index.php/2017/03/23/perfil-racial-dos-docentes-da-uspanalisa-baixo-indice-de-professores-negros/. Acesso em 07 set. 2019.

MATTHEWS, Christopher N.; LEONE, Mark P.; JORDAN, Kurt A. The political economy of archaeological cultures: Marxism and American historical archaeology. Journal of Social Archaeology, v. 2, n. 1, p. 109-134, 2002.

MBEMBÉ, Achille. Necropolitica. São Paulo: n-1 Edições, 2018.

MCDAVID, Carol. 2010. Public archaeology, activism, and racism: rethinking the heritage "product". In: STOTTMAN, M. Jay (ed.) Archaeologists as activists: can archaeologists change the world? Tuscaloosa (Alabama/EUA): University of Alabama Press, 2010. p. 36-47.

MCGUIRE, Randall. Arqueologia como ação política: o projeto guerra do carvão no Colorado. Revista do Museu de Arqueologia e Etnologia, v. 3, p. 387-397, 1999.

MESKELL, Lynn. The intersections of identity and politics in archaeology. Annual Review of Anthropology, v. 31, p. 279-301, 2002.

MILLER, Daniel. Consumo como cultura material. Horizontes Antropológicos, v. 13, n. 28, p. 33-63, 2007.

MIZRAHI, Mylene. Cabelos ambíguos: beleza, poder de compra e "raça" no Brasil urbano. Revista brasileira de Ciências Sociais, v. 30, n. 89, p. 31-45, 2015.

MULLINS, Paul. Racializing the commonplace landscape: an archaeology of urban renewal along the color line. World Archaeology, v. 38, n. 1, p. 60-71, 2006.

MUNANGA, Kabengele. Negritude afro-brasileira: perspectivas e dificuldades. Revista de Antropologia, v. 33, p. 109-117, 1990.

MUNANGA, Kabengele. Algumas considerações sobre "raça", ações afirmativas e identidade negra no Brasil: fundamentos antropológicos. Revista USP, v. 68, p. 46-57, 2005-2006.

MUNANGA, Kabengele. Por que ensinar a história da África e do negro no Brasil de hoje? Revista do Instituto de Estudos Brasileiros, v. 62, p. 20-31, 2015.

NASCIMENTO, Anna B. O impacto do colorismo no feminismo negro no Brasil. Cadernos Humanidades em Perspectivas, v. 4, n. 2, p. 57-61, 2018.

NORWOOD, Kimberly J. "If You Is White, You's Alright..." Stories about colorism in America. Washington University Global Studies Law Review, v. 14, n. 4, p. 585-605, 2015.

OLSEN, Bjørnar. Material culture after text: re-membering things. Norwedian Archaeological Review, v. 36, n. 2, p. 87-104, 2003.

ORSER JR, Charles; FUNARI, Pedro Paulo. Arqueologia da resistência escrava. Cadernos LEPAARQ, v. 1, n. 2, p. 11-25, 2004.

ORSER JR., Charles. The challenge of race to American Historical Archaeology. American Anthropologist, v. 100, n. 3, p. 661-668, 1999. 
ORSER JR., Charles. The Archaeology of Race and Racialization in Historic America. Tallahassee (Flórida/EUA): University Press of Florida, 2007.

PADRÓS, Eduardo S. América Latina: ditaduras, segurança nacional e terror de Estado. História e lutas de classe, v. 4, n. 4, 43-49, 2012.

PASSOS, Lara de P. Arqueopoesia: uma proposta feminista afrocentrada para o universo arqueológico. Dissertação (Mestrado em Antropologia) - Faculdade de Filosofia e Ciências Humanas, Universidade Federal de Minas Gerais, Belo Horizonte, 2019.

PEARSON, Marlys; MULLINS, Paul R. Domesticating Barbie: an archaeology of Barbie material culture and domestic ideology. International Journal of Historical Archaeology, v. 3, n. 4, p. 225259, 1999.

PEIRANO, Mariza. Sem lenço, sem documento: reflexões sobre cidadania no Brasil. Sociedade e Estado, v. 1, n. 1, p. 49-64, 1986.

PENA, Sergio D. Razões para banir o conceito de raça da medicina brasileira. Manguinhos, v. 12, n. 2, p. 321-346, 2005.

PEREIRA, Ricardo; CHEVITARESE, André L. Por uma arqueologia dos candomblés: contribuições da ciência do passado aos estudos dos fenômenos religiosos. Revista Maracanan, v. 20, p. 112-136, 2019.

PEREIRA, Rodrigo. Por uma outra diáspora: formação histórica e dispersão dos terreiros de candomblé no Grande Rio. Revista de História Bilros, v. 2, n. 3, p. 125-152, 2014.

POMPEU, Fernanda; MUNANGA, Kabengele. Kabengele Munanga, professor. Geledés - Instituto da Mulher Negra, 2017. Disponível em: https://www.geledes.org.br/kabengele-munangaprofessor/. Acesso em 20 mar. 2020.

PRADA, Monique. Putafeminista. São Paulo: Veneta, 2018.

QUADFLIEG, Jutta M. Fundamental properties of afro-american hair as related to their straightening/relaxing behaviour. Tese (Doutorado em Ciências Naturais) - Faculdade de Matemática, Ciência da Computação e Ciências Naturais, Rheinisch-Westfalischen Technischen Hochschule Aachen, 2003.

QUIJANO, Aníbal. Colonialidade do poder e classificação social. In: SANTOS, Boaventura S.; MENESES, Maria Paula. (org.) Epistemologias do Sul. Coimbra: Almedina, 2009. p. 73-117.

RIBEIRO, Djamila. O que é lugar de fala? Belo Horizonte: Letramento, 2017.

RIBEIRO, Loredana. Crítica feminista, arqueologia e descolonialidade: sobre resistir na ciência. Revista de Arqueologia, v. 30, n. 1, p. 210-234, 2017.

RIZVI, Uzma Z. Checkpoints as gendered spaces: an autoarchaeology of war, heritage and the city. In: GRAVES-BROWN, Peter; HARRISON, Rodney; PICCINI, Angela. (ed.) The Oxford Handbook of the Archaeology of the Contemporary World. Oxford (UK): Oxford University Press, 2013. p. 497-507.

ROSEMAN, Michele T. Hairlooms: the untangled truth about loving our natural hair and beauty. Deerfield Beach (Florida/EUA): Health Communications Inc, 2017.

SALES JÚNIOR, Ronaldo. Democracia racial: o não-dito racista. Tempo Social, v. 18, n. 2, p. 229 250, 2006.

SANSONE, Livio. Os objetos da identidade negra: consumo, mercantilização, globalização e a criação de culturas negras no Brasil. Maná, v. 6, n. 1, p. 87-119, 2000.

SANTOS, Vanicléia S., SYMANSKI, Luís C.; HOLL, Augustin. (org.) Arqueologia e história da cultura material na África e na diáspora africana. Curitiba: Prismas, 2018.

SCHAMBERGER, Karen. Resistance, advocacy and education: collecting and exhibiting "race". Museums Australia National Conference, p. 146-151, 2010. 
SCHOFIELD, John. Archaeology and contemporary society: an introduction. World Archaeology, v. 42, n. 3, p. 325-327, 2010.

SCHWARCZ, Lilia M. As teorias raciais, uma construção histórica de finais do século XIX: o contexto brasileiro. In: SCHWARCZ, Lilia M.; QUEIROZ, Renato S. (org.) Raça e diversidade. São Paulo: Edusp, 1996. p. 147-185.

SCHWARCZ, Lilia M. Nem preto nem branco, muito pelo contrário: cor e raça na sociabilidade brasileira. São Paulo: Claroenigma, 2012.

SCHWARCZ, Lilia M. O espetáculo das raças: cientistas, instituições e questões raciais no Brasil (1870-1930). São Paulo: Companhia das Letras, 1993.

SILLIMAN, Stephen W. Culture Contact or Colonialism? Challenges in the Archaeology of Native North America. American Antiquity, v. 70, n. 1, p. 55-74, 2005.

SILVA, Nelson V. Extensão e natureza das desigualdades raciais no Brasil. In: GUIMARÃES, Antonio S.; HUNTLEY, Lynn. (org.) Tirando a máscara: ensaios sobre racismo no Brasil. São Paulo: Paz e Terra, 2000. p. 33-52.

SOUZA, Marcos A. Por uma arqueologia da criatividade: estratégias e significações da cultura material utilizada pelos escravos no Brasil. In: AGOSTINI, Camilla. (org.) Objetos da escravidão: abordagens sobre a cultura material da escravidão e seu legado. Rio de Janeiro: 7Letras, 2013. p. 11-36.

SPIVAK, Gayatri C. Pode o subalterno falar? Belo Horizonte: Edufmg, 2010.

SYMANSKI, Luís C. A arqueologia da diáspora africana nos Estados Unidos e no Brasil: problemáticas e modelos. Áfro-Ásia, v. 49, p. 159-198, 2014.

TAUSSIG, Michael. Culture of terror-space of death: Roger Casement's Putamayo report and the explanation of torture. Comparative studies in society and history, v. 26, n. 3, p. 467-497, 1984

TELES, Janaina. Métodos e técnicas de ocultação de corpos na cidade de São Paulo. Relatório/Comissão da Verdade do Estado de São Paulo "Rubens Paiva". Tomo I - Parte I - Capítulo 3. São Paulo: Assembleia Legislativa, 2015.

TERTO, Amauri. Apenas 3\% das bonecas à venda em lojas virtuais no Brasil são negras, aponta estudo. Geledés - Instituto da Mulher Negra, 2016. Disponível em: https://www.geledes.org.br/apenas-3-das-bonecas-venda-em-lojas-virtuais-no-brasil-saonegras-aponta-estudo/. Acesso em 19 out. 2019.

WHEELER, Kathleen. Theoretical and methodological considerations for excavating privies. Historical archaeology, v. 34, n. 1, p. 3-19, 2000.

ZARANKIN, Andrés; SALERNO, Melissa. Sobre bonecas e carrinhos: desconstruindo as categorias "feminino" e "masculino" no passado. Especiaria, v. 11/12, n. 20/21, p. 219-240, 2010.

ZEDEÑO, Maria I. Landscapes, land use, and the history of territory formation: an example from Puebloan southwest. Journal of archaeological method and theory, v. 4, p. 63-103, 1997. 